\title{
El triángulo azul: el teatro como recurso de sobrevivencia y espacio de memoria ${ }^{1}$
}

El triángulo azul es un vodevil sobre el Holocausto, de Laila Ripoll y Mariano Llorente, que recupera la memoria de los españoles republicanos que acabaron en Mauthausen. La fábula se basa en dos historias reales: el escondite y preservación de muchas de las fotografías sobre la barbarie nazi que dos españoles realizaron, y el vodevil que un grupo de prisioneros republicanos montó en la navidad de 1942 en el campo. Siguiendo el análisis de Marianne Hirsch, la obra puede considerarse como un ejemplo de postmemoria. En este ensayo se revisa desde una perspectiva dramática cómo se reconstruye, recupera y representa la identidad de algunos de esos olvidados del Holocausto, así como la importancia política de la obra teatral, sobre todo en términos de lo que ha significado el olvido.

Según Eva Hoffman, vivimos la era de la memoria (203). Esto implica la necesidad social de contar las historias de otros y transmitir lo que Susan Sontag ha descrito como other people's pain. Marianne Hirsch explica que esta inclinación por recuperar y a la vez reescribir las historias de otros crea una especie de conexión, un tipo de transferencia hacia aquellas generaciones que no experimentaron los acontecimientos traumáticos que la memoria pretende revivir (18-19). Los miembros de estas generaciones, a las que Hoffman denomina postgeneraciones, reconocen que las memorias que han recibido son claramente distintas de las de quienes fueron testigos de esos actos o, incluso, de quienes los sufrieron (Hoffman 203). Hirsch denomina como postmemoria a este tipo de memoria transmitida. Asimismo, considera que la conexión de la postmemoria con el pasado "is thus actually mediated not by recall but by imaginative investment, projection, and creation" (5). Por su parte, Aleida Assmann distingue las formas de transmisión de la memoria y explica lo que Maurice Halbwachs denominó memoria colectiva. Para ella, la memoria transmitida biográfica y factualmente tiene como principal vehículo la familia y la conceptualiza como memoria comunicativa. Este tipo de memoria la contrasta con la memoria colectiva, "an institutionalized hegemonic archival memory". Una vez que las memorias integran el archivo hegemónico, "they can be exchanged, shared, corroborated, confirmed, corrected, disputed and ... written down" (Assmann 36). Al 
formar parte del ámbito hegemónico, las memorias también pueden ser suprimidas y hasta negociadas políticamente, como ha sucedido en España.

El tema de la memoria histórica en España se ha relacionado por lo general con las víctimas de la Guerra Civil y la posguerra y ha dejado fuera, extrañamente, a las víctimas republicanas del Holocausto, como si se tratase de dos colectivos diferentes cuando, en realidad, ambos caben en lo que algunos investigadores como Montse Armengou, Ricard Belis y Paul Preston denominan "the Spanish Holocaust". En el año 2000 aparecen en España las primeras manifestaciones de un movimiento político que se erige como resistencia al olvido "pactado" después de la muerte del dictador Francisco Franco y de los casi cuarenta años de dictadura militar, y que se conoce como Movimiento por la Recuperación de la Memoria Histórica (MRMH). Según Manuel Parodi Muñoz, "hasta ahora no existe un criterio unificado sobre lo que significa recuperación de la memoria histórica, por lo que su significado está abierto a la interpretación" (7; cursiva en el original). ${ }^{2}$ Sin embargo, cuando se aprobó la Constitución de 1978, uno de los puntos sobresalientes del evento fue precisamente el deseo por sellar la reconciliación entre vencedores y vencidos, un elemento que el MRMH pone en entredicho. ${ }^{3}$ No será hasta el 31 de octubre de 2007, casi treinta años después de la aprobación de dicha Constitución, que entrará en vigor la Ley de Memoria Histórica, que supuestamente buscaría concluir el capítulo de la Guerra Civil y lograr una reconciliación entre los bandos que históricamente fueron enemigos. Esta ley buscaba reconocer y ampliar derechos, y establecer medidas a favor de quienes padecieron persecución o violencia durante la Guerra Civil y la dictadura (Agencia Estatal).

Los alcances de esta ley fueron mínimos y duramente criticados por la Asociación para la Recuperación de la Memoria Histórica (ARMH), para quien los delitos del franquismo no eran una cuestión personal y familiar, como la ley lo indicaba, sino crímenes cometidos contra la sociedad y la humanidad que exigían un tratamiento igual al que se aplicaba a los casos de lesa humanidad, como los del Holocausto. Es así que la Ley de Memoria Histórica resultó una terrible decepción, y muchas asociaciones memorialistas la consideraron una propuesta vergonzosa. Es además prueba de que la cuestión de la memoria histórica sigue siendo un asunto pendiente hasta nuestros días y de que el Estado español no ha enfrentado su responsabilidad política, ni mucho menos ha logrado una reconciliación. Por el contrario, como apunta María Delgado, el gobierno ha respaldado una desmemoria institucional - lo que, para Milan Kundera, representa el organized forgetting (Delgado 178) - muy acorde con lo que Franco en su 
época intentó. Por su parte, Parodi Muñoz propone una interesante tesis sobre el pacto de reconciliación y el rechazo que ha tenido entre un gran segmento de la sociedad. De acuerdo con su análisis, el "pacto" de la Transición fue producto de la suma de intereses entre los vencedores (de la Guerra Civil) y "una élite de los vencidos" que buscaba formar parte del grupo de los vencedores "mediante la reconciliación con ellos" (9). Asimismo, explica que, para quienes defendieron este pacto, la reconciliación es en realidad un "sometimiento de los vencidos a los vencedores y sus leyes", opuesto a como lo entienden los memorialistas, a saber, "un trato en completa igualdad de condiciones de ambas partes" (9). Por lo tanto, la recuperación de la memoria histórica, según Parodi Muñoz, "significa la recuperación de un equilibrio de fuerzas" con miras a hacer realidad esa posibilidad (9).

La literatura ha tenido un papel preponderante en la recuperación de la memoria en lo que concierne a las víctimas de la Guerra Civil y de la posguerra franquista, y lo ha hecho de manera paralela a las distintas asociaciones civiles que se crearon como resistencia al olvido. Como señala Parodi Muñoz, los escritores que trabajan estos temas intentan exponer sus puntos de vista sobre este capítulo de la historia española y todos ellos han participado activamente en "moldear la memoria colectiva" (8); sin embargo, no deja de ser curioso que la lista de creadores que se involucran en estos temas sea principalmente de autoría masculina, al menos hasta finales del siglo pasado. Asimismo, es cierto que ha sido sobre todo en el ámbito de la novela en donde más se encuentran narrativas que recuperan y rescriben sucesos relacionados con la Guerra Civil Española y la posguerra, aunque también en el teatro hemos de ver importantes aportaciones. ${ }^{4}$

Resulta notable que todo lo contrario haya sucedido con otro de los capítulos de la historia mundial - muy cercano temporal y políticamente a la Guerra Civil Española y la posguerra - que lejos de ser olvidado, ha sido reivindicado tanto por las historias oficiales como por distintos actos de memoria histórica: el Holocausto de la Segunda Guerra Mundial, de cuyo final este último 2015 se celebraron los setenta años. Novelas, películas, pinturas y esculturas sobre las atrocidades que los nazis alemanes realizaron contra los judíos han ido forjando nuevamente en el imaginario colectivo una memoria histórica vívida y clara, y no solo han permitido la conmemoración, sino que la han hecho estéticamente poderosa. Para muchos de los autores que han trabajado la memoria histórica sobre la barbarie nazi, ha sido muy importante intentar "to keep the consciences of the living alert and vigilant by familiarizing them with the sufferings of the Holocaust victims, the cruelty of their persecutors and the callousness of 
many witnesses to the crime", como lo sugiere Zygmunt Bauman (Engelking vii). La enorme lista de títulos sobre este tema, incluso la creación de los Estudios sobre el Holocausto que varias universidades han incorporado dentro de sus ofertas académicas, nos muestran no solo la importancia de la memoria histórica, sino también que su rescritura responde a intereses hegemónicos, de manera que lo que más se ha representado ha sido el exterminio nazi de judíos, dejando de lado prácticamente en el olvido - a otros importantes colectivos que fueron igualmente torturados, explotados $\mathrm{y}$, en última instancia, exterminados. Asimismo, de acuerdo con Ghassan Hage, algunas de las narrativas poscoloniales sobre el Holocausto le han asignado a la figura de la víctima, sobre todo la judía, una posición de superioridad moral absoluta e incontestable (Bennett 5), que sin duda ha funcionado como una inversión política en los años posteriores. ${ }^{5}$ De hecho, el término Holocausto se ha construido como sinónimo de exterminio judío, y su definición implica, según la Enciclopedia Britannica, "the systematic state - sponsored killing of six million Jewish men, women and children, and millions of others by Nazi Germany and its collaborators during World War II. The Germans called this 'the final solution to the Jewish question'"

Dentro de la ambigua categoría others se encuentran las víctimas no judías, para quienes el panorama no puede ser más diferente en términos del reconocimiento y la memoria. Algunos de los marginados de la memoria del Holocausto han sido los españoles antifranquistas, en su mayoría republicanos, que al exiliarse en Francia fueron capturados por los nazis. Los nazis de hecho intentaron "devolverlos" a la España franquista, quien los rechazó de manera terminante. ${ }^{6}$ Este trabajo examina la propuesta teatral por recuperar la memoria de un colectivo olvidado, marginado de las memorias del Holocausto nazi, que Laila Ripoll y Mariano Llorente hacen en su obra El triángulo azul (2014). Me interesa revisar desde una perspectiva dramática cómo se reconstruye, recupera y representa la identidad de algunos de esos olvidados del Holocausto, así como la importancia política de una obra teatral como la que estaremos examinando, sobre todo, lo que ha significado el imperdonable olvido. ${ }^{7}$

En la dramaturgia española contemporánea, el trabajo de Laila Ripoll es una referencia necesaria en cuanto a teatro de la memoria y cuenta en su haber con tres obras importantes: Atra Bilis (2001-2003), Los niños perdidos (2005) y Santa Perpetua (2010). En el caso de Atra Bilis tenemos a cuatro ancianas que desempolvan recuerdos y rencores durante el velorio del esposo de una de ellas: "Una inválida, una virgen, una burra y una idiota. Sus recuerdos son la historia de España, o mejor, de las dos Españas que nos matan de risa y nos hielan el corazón. Humor y terror en una no- 
che de tormenta" (Galindo). Los niños perdidos, por su parte, recupera la memoria de aquellos niños huérfanos de la Guerra Civil y del franquismo. Itzíar Pascual puntualiza lo siguiente respecto a la obra:

Lázaro sabe presentarnos el mundo de la Organización Juvenil, de esas Hermanas (¿debería escribirlo en cursiva?) que rompen las cartas y los tebeos, que amenazan, que injurian ... Es el resultado de un exquisito proceso documental, en el que Laila toma, sorbo a sorbo, los ecos de los hechos, los testimonios, los documentos ... Pero a la vez, dotándolos de una consistencia poética y profundamente teatral. Porque esos niños que no crecen, que no se hacen mayores, resistentes en el desván de los olvidos, rodeados de fantasmas del pasado, ¿no son ellos mismos sombras de lo que fueron? (4)

Finalmente, en Santa Perpetua tenemos la historia de "un nieto [que] viene a reclamar la bicicleta oxidada del abuelo desaparecido en una fosa común aún no encontrada" (Reck 63).

En los tres casos es posible identificar la poética de Ripoll respecto al tratamiento de los temas de la memoria: un teatro de lo grotesco, a medio camino entre Goya y Valle-Inclán, en donde las situaciones monstruosas se matizan con el humor negro. En los tres casos, Ripoll da cuenta de los distintos horrores vividos en la Guerra Civil y en la posguerra y, como señala Isabelle Reck, habla de la "verdad insoportable" (60). En 2014, Ripoll junto a Mariano Llorente publica y estrena El triángulo azul, su última obra sobre la desmemoria histórica. ${ }^{8}$ Se trata de un musical grotesco que recupera la historia, casi desconocida, de muchos de los españoles republicanos que se exiliaron en Francia durante y después de la Guerra Civil española y que, finalmente, fueron a parar en algún campo de concentración nazi. Ripoll y Llorente se ocupan de los españoles enviados a Mauthausen, el campo de exterminio nazi en Austria, pero no producen una obra estrictamente histórica ni testimonial. Nunca como ahora la historia y la memoria se entremezclan, compiten entre sí y, al final, coinciden en una fábula que intenta abrir un espacio propio para las víctimas españolas de Mauthausen, pero con una clara carga de reclamo crítico. A diferencia de su trilogía de la memoria, en El triángulo azul varios de los personajes principales están basados en personas reales que vivieron y sufrieron los horrores de Mauthausen, o en quienes infligieron el horror. Esta reapropiación del dolor y el trauma sufrido por otros es lo que constituye, según Marianne Hirsch, la postmemoria. Se trata de actos de transferencia que transforman hechos históricos en actos de memoria: "Memory is mediated, cultural, but it has also escaped through the open doorway ... to haunt the natural landscapes of the present" (25). 
Uno de los reclamos formulados en la obra de Ripoll y Llorente tiene que ver con el desconocimiento que los españoles tienen de la existencia de estas víctimas, producto de la supresión de la memoria que fue pactada por las fuerzas políticas después de la muerte de Franco. Como ha documentado Carlos Hernández, de los más de nueve mil españoles que acabaron en los campos de concentración nazi, 7532 terminaron en Mauthausen y los subcampos que de este dependían, en donde murieron más de 48oo. Es legítimo afirmar entonces que Mauthausen representa el infierno de los presos republicanos españoles. La fábula de El triángulo azul se basa en dos hechos reales: una es la historia de dos españoles que lograron poner a salvo una serie de fotografías sobre la barbarie que se llevaba a cabo en el campo, imágenes que fueron determinantes para inculpar a varios responsables del exterminio en Mauthausen, pero sobre todo, evidencian la necesidad de preservar una memoria que, en aquel momento, corría el riesgo de extinguirse. De igual manera, la fábula recupera la historia del grupo de españoles que logró obtener el permiso, en medio del mismísimo infierno, para montar una revista musical. De manera inexplicable (o no tan inexplicable), ambas historias estuvieron sepultadas en el olvido histórico durante medio siglo. Francisco Boix, uno de los dos españoles encargados de hacer las copias y después de sacarlas de Mauthausen, murió en 1951, tras haber narrado el horror de vivir en el campo de Mauthausen, como lo muestra el documento que da prueba del interrogatorio del Juicio a los principales criminales de guerra alemanes. Boix murió a los 30 años, en París, sin pena ni gloria.

No será sino hasta el año 200o, cuando Lorenzo Soler produce un documental con el título Francisco Boix, un fotógrafo en el infierno, que la memoria de este héroe republicano español empezará a recuperarse. Asimismo, en 2002 Benito Bermejo publica Francisco Boix, el fotógrafo de Mauthausen. Fotografías de Francisco Boix y de los archivos capturados a los SS de Mauthausen. ${ }^{9}$ Además, para 2016 está planeada la publicación de una novela gráfica titulada Le Photographe de Mauthausen que narra la historia de Francisco Boix y el robo de las fotografías. El guión ha estado a cargo de Salva Rubio, quien lo ha adaptado de un guión cinematográfico propio y los dibujos son de Pedro J. Colombo. Otro de los españoles responsables de sacar las fotografías que servirían como pruebas fehacientes del exterminio nazi en Mauthausen fue Antoni García, de quien sabemos poco, más allá de que aparentemente llegó al campo antes que Boix y que el exceso de trabajo en el laboratorio fue la razón por la cual se integrara al laboratorio en el que estaba otro español de nombre José Cereceda. ${ }^{10} \mathrm{La}$ segunda historia tiene que ver con el vodevil titulado "El Rajá de Rajaloya" que un grupo de prisioneros españoles en Mauthausen montó en la 
navidad de 1942 con la anuencia de las autoridades del campo. Resulta muy fácil entender la atracción de los autores por recuperar un suceso no solo insólito y prácticamente desconocido, sino además increíble, dadas las características del lugar en cuestión.

Esos son los hechos que inspiran la fábula, cuya historia nos la narra el recuerdo de un suboficial nazi, Paul Ricken, director del Servicio de identificación fotográfica, quien mira al pasado para intentar explicar a sus hijos lo inexplicable: el terrible exterminio organizado de millones de seres humanos. Una de las características de esta complejísima obra es que maneja tres tiempos y tres espacios dramáticos diferentes correspondientes a distintos escenarios. Por un lado, tenemos el tiempo de la narración, que se realiza durante el mes de junio de 1965, en la casa de Paul Ricken, en Colonia. El segundo lugar es el campo de concentración de Mauthausen en Alta Austria, en donde está ubicado el laboratorio fotográfico y al cual le corresponde los años de 1940-1945. Es allí donde se construyen las historias de Toni, Paco, La Begún, Jacinto, Oana, Brettmeier, así como de los Músicos 1, 2 y 3 . El tercer escenario constituye la sala de cine de los SS de Mauthausen en el año 1942, cuando se estrenó la revista musical en la que participaron los presos 1, 2, 3, 4, 5 y 6, así como los músicos 1, 2 y 3. Tanto los espacios como los tiempos se intercalan y, a veces, se superponen, creando una especie de lo que Hirsch llama flashes of imagery, lo que sin duda ayuda a reflejar la naturaleza fragmentaria de la postmemoria del trauma (31). No obstante, esta estructura espaciotemporal permite darle una identidad memorable a dos historias y dos colectivos que han estado injustamente en el olvido: por un lado, los personajes involucrados en la extracción de las famosas fotografías, a saber Toni, Paco, Jacinto y la gitana Oana; por el otro, los prisioneros gitanos y españoles que intentaron resistir los embates de la barbarie y, a la vez, ofrecer fuerza y apoyo moral a los que aún sobrevivían el infierno mediante la producción del vodevil "El Rajá de Rajaloya”. El tercer espacio está dedicado al representante del bando nazi y su necesidad de autojustificación. La inclusión de la voz nazi en una narrativa sobre el Holocausto es interesante y poco común, y tiene por efecto equilibrar la fábula.

El telón se abre con el narrador nazi Paul Ricken, un hombre roto, quien en un acto de memoria individual está intentando justificar lo injustificable. A medida que avanza su relato, nos percatamos de que está grabando su propia historia, en la sala de su casa, y que corre el año de 1965. Los ausentes interlocutores son sus hijos, en cuyos ojos Ricken ha visto siempre la misma pregunta: ¿por qué? Ricken empieza su historia, que se remonta a 1935, cuando ingresa las SS, para ser enviado al campo de 
concentración de Mauthausen en 1939, en Austria. La introducción de Ricken está acompañada por uno de los elementos dramáticos más distintivos de la obra: la música, que tiene un valor narrativo esencial a lo largo de la trama, no solo porque la propuesta dramática es de hecho una revista musical del tipo vodevil, sino porque además aporta un soporte simbólico que intensifica la fuerza dramática de la escena. Esto lo podemos apreciar en el inicio, cuando Ricken intenta una autojustificación mientras escuchamos como música de fondo las notas de la suite No. 1 de Bach:

Bach, Schumann, Beethoven, Brahms ... Webern ... siempre he creído que el arte nos acerca a Dios, que nos convierte en mejores personas, que nos eleva a la condición de santos y nos aleja de las bestias ... Siempre consideré que el hombre es capaz de grandes cosas. Siempre estuve convencido de que el hombre es un ser sublime, un ser habitado por la fuerza y el espíritu, capaz de la mayor comprensión, de generar la mayor belleza, de la mayor bondad. Capaz de tocar la gloria con la punta de los dedos, de realizar actos buenos y hermosos, capaz de lo mejor. (Ripoll y Llorente 2)

El contraste entre la grandeza musical de Bach como música de fondo para narrar la monstruosidad de los actos que Ricken ha fotografiado y, de cierta manera aceptado, puede considerarse un ejemplo de la ironía dramática ripoliana, a la que ya nos tiene acostumbrados.

La música en la obra también reproduce la identidad políticamente construida de los personajes históricos y de los otros colectivos que no han sido reconocidos por las narrativas mainstream del Holocausto, como los gitanos: "De entre las brumas de la memoria de Ricken emergen tres músicos gitanos tocando un pasodoble ... La orquesta gitana se arranca con el 'Adiós a la vida' a su manera, zíngara y alegre" (3-4). Desde el inicio, contrastamos como espectadores/lectores el discurso imperialista nazi con las narraciones de resistencia de los diversos colectivos representados en la obra, tanto de manera narrativa como musical. El discurso del poder siempre se ve acompañado de música clásica, ya sea alguna suite de Bach o algún aria de la ópera Tosca. Por el contrario, las historias de los olvidados siempre se cantarán y narrarán acompañadas de algún chotis, de algún pasodoble o incluso de alguna copla. Este contraste tan evidente nos permite percibir una crítica a la narrativa de supuesta superioridad que Kundera satiriza: "They are convinced they are part of a grand, positive evolution; or they are convinced they live in a great tragedy - either way, they are convinced they are to live in greatness" (Kakutani). Es importante notar también que la utilidad dramática de los músicos gitanos en la obra es esencial: funcionan como el antiguo coro griego, tanto para introducir los contextos, como para ayudar al espectador a seguir los sucesos, o 
incluso, hacen comentarios, muchas veces sarcásticos, sobre el tema. El juego entre alta y baja cultura es fácilmente perceptible y un excelente facilitador del contraste. ${ }^{11}$ Volveremos al tema de la música más adelante.

Preso 1:

Señores de la orquesta, atención: les ruego que me toquen ... otra canción.

Pasodoble de "El Triángulo azul"

Triángulos de colores

para niños y mayores.

Los rojos son los políticos

y amarillos los semíticos.

Verdes para delincuentes,

que todos son prominentes.

Y para los mariposa

triangulitos color rosa.

Los gitanos de marrón,

morados por religión,

los negros para asociales,

para putas y anormales.

Yo, que soy republicano

quiero un triángulo encarnado.

No señor, que azul será

el color que lucirá

esta tropa de españoles,

y otro color no enarboles

pues que España te ha expatriado

y solito te has quedado.

De los sin patria el color

es el que cuadra mejor. (4-5)

Una de las estrategias narrativo-dramáticas más sobresalientes de la obra es el peso de la rescritura de la vida de algunos de los personajes centrales, como Toni y Paco, o incluso Oana, la gitana a la que han obligado a prostituirse. A pesar de su naturaleza claramente heroica, se trata de personajes de carne y hueso, con cualidades y defectos. Desde el inicio sabemos que Toni y Paco, aunque ambos son españoles y están involucrados en la tarea de hacer copias extras de cada foto y esconderlas 
o bien de ir escondiendo negativos de todo lo que sucedía en el campo, chocan a cada instante:

(Silencio. Suena un disparo de fusil. Paco se acerca e intenta ver algo a través de unos agujeritos que hay en las cortinas negras del ventanuco. Suena ahora un disparo de revólver)

Paco: ¿Por qué llamaremos a eso tiro de gracia? Tampoco tiene ninguna gracia. Toni: Está terminantemente prohibido mirar.

Paco: A este paso se va a hacer de noche. Mira, la mano de uno de los muertos ha caído sobre el rostro del otro. Parece que le dice "no mires, no mires", que los alemanes son muy feos...

Toni: Si entra algún SS y te ve mirando, nos pueden fusilar a todo el Kommando.

Paco: Mirándolo bien, ahora se les ve a gusto, ahí, encima del carro ese, abrazaditos...

Toni: (Llegando hasta donde está Paco) Te lo pido por favor, para ya, te lo suplico, cállate. Están matando gente ahí fuera y yo no lo quiero ver, no me lo cuentes tú, hijo de puta, no me lo cuentes tú...

Paco: ¿Crees que esto me hace gracia, Toñete?

Toni: No me llames, Toñete, y si no te hace gracia, ¿por qué cojones te ríes?

Paco: ¡Porque me da la gana, me río porque me da la gana! Me río por lo graciosa que es nuestra vida aquí, me río porque todo tiene una gracia que te partes de risa, por eso me río, Toñete, por eso me río, porque se me acumulan las imágenes en la cabeza, como negativos de fotografías, cientos de imágenes, miles de imágenes ... Por eso me río. (II-I2)

De hecho, cada uno de los españoles en el laboratorio fotográfico empezará por separado a tratar de guardar o esconder el material sin el conocimiento del otro, lo que sin duda les da una dimensión muy humana. No se trata de superhombres ni de personas extraordinarias, por el contrario, son dos compatriotas que apenas se toleran y desconfían el uno del otro. No obstante, cuando Toni cae enfermo y tiene que pasar tiempo en la enfermería, será Paco quien encuentre las fotos que Toni ha estado escondiendo y decida sacarlas del campo, con la ayuda de Oana y de Jacinto, lo que Toni nunca le perdonará. De cierta manera, Paco se vuelve el líder intelectual del plan de preservación de la memoria, y su personalidad alegre y cínica le permite convencer al resto del equipo para que coopere. 
La agencia que estos personajes demuestran, a pesar de encontrarse en las peores circunstancias posibles, es trágica en sí misma. La memoria no puede extinguirse, la barbarie y la perversión de los nazis en Mauthausen no pueden ser ignoradas. Irónicamente, la supervivencia de la memoria se vuelve la fuerza para actuar y resistir y, sin embargo, pareciera ser que no ha sido suficiente para garantizar que la memoria de esos miles de españoles en Mauthausen y otros campos de exterminio se mantuviese viva y se celebrase después.

Oana, por su parte, es una de las tantas jóvenes gitanas que fueron violadas repetidas veces y luego obligadas a prostituirse para poder sobrevivir el exterminio, aunque al final también es sacrificada. ${ }^{\mathrm{I}}$ Es un personaje muy relevante, primero porque es la única referencia que la obra hace a la suerte de las mujeres en los campos de concentración, y además porque su etnicidad, considerada como inferior por los nazis, aparentemente ha sido una de las razones por las cuales no se ha considerado importante recuperarla en los esfuerzos de memoria histórica:

En prostíbulo, Enero 1942. Martin Brettmeier y una prostituta, Oana.

Brettmeier: Dicen que tengo sangre gitana. No me lo dicen a la cara. Pero sé que lo dicen. ¿Tú crees que tú y yo podemos tener la misma sangre?

Oana: No.

Brettmeier: Me hubiera gustado que hubieras dicho que sí. Así, te hubiera matado aquí mismo y hoy al menos habría pasado algo. Hay días muy tontos en Mauthausen.

Oana: ¿Hoy es un día tonto?

Brettmeier: Sí, porque está quieto, no pasa nada, no hace viento, no llueve, no nieva, nada, todo quieto. Hoy no ha llegado ningún tren.

Oana: Llegarán mañana, o pasado mañana.

Brettmeier: Pero hoy es un día tonto. Los días que no llegan trenes son días muy tristes en Mauthausen. ¿Qué te dicen de mí mis camaradas?

Oana: Todo el mundo dice muchas cosas de todo el mundo y yo no digo nada.

Oana: ¿Quién va a morir?

Brettmeier: Tu raza ... todo lo ensucia ¿Sabes? Los judíos no me dan asco, ni me producen temor, ni lástima. Son molestos como piojos y como piojos van a morir. Sin embargo, tu raza, me asquea porque huele a sarna y sabe a delito. ¿Te gusta esa música?

Oana: Es el austríaco, ¿no? 
Brettmeier: ¿Conocerás también su nombre?

Oana: No. Sólo sé que se escapó un austríaco y que le habéis cogido.

Brettmeier: ¿Por qué lo sabes? ¿Por quién lo sabes?

Oana: Porque no paráis de hablar. Hoy he aprendido que mi raza ... todo lo ensucia.

Y que sabe a delito. (8-9)

Oana será quien ayude a Jacinto, el joven español que trabajaba fuera del campo de concentración y pasaba por el pueblo junto al campo, en donde conoció a una mujer austriaca enemiga de los nazis, quien esconderá una buena parte de las fotografías. Oana, Jacinto y Paco logran conocerse y entre los tres llevan a cabo el plan de ir sacando las fotografías del campo, sobre todo después de la derrota de los nazis en Stalingrado. Paco es sin duda el personaje más cuestionador y sarcástico de la historia. Su humor negro y el agrio sarcasmo que lo definen resultan insoportables para Toni, quien vive casi paralizado de miedo y quien se negará a formar parte del plan. La antipatía entre ambos personajes vuelve la historia más creíble, porque, como lo señalamos arriba, nos revela a héroes con defectos y cualidades, y por ende, más cercanos a los espectadores.

Junto con los prisioneros claramente heroicos también están los traidores, capaces de cualquier cosa con tal de evitar la muerte. Tal es el caso de La Begún, otro español que se dedica a matar prisioneros franceses, los empuja por el precipicio de la cantera. La Begún odia a sus compatriotas y, con tal de gozar de la simpatía de Brettmeier, el dirigente del campo, acepta espiarlos para delatarlos. La Begún sospecha que algo se está tramando, por lo que tortura y amenaza al joven Jacinto, quien sin embargo lo resiste y no traiciona la causa por la que se está jugando la vida. El suspenso que la obra logra construir alrededor del destino de los tres personajes centrales en el plan de las pruebas fotográficas es otro elemento importante no solo para mantener la tensión en el espectador/lector, sino también para comunicar el alto riesgo que estos tres presos corrían día tras día. De cierta manera, funciona como un ingrediente de memorabilidad, ya que como lectores/espectadores experimentamos angustia ante la posibilidad de que alguno de los protagonistas del plan sea pillado, porque podemos imaginar las terribles consecuencias que enfrentarían. De igual modo, es interesante descubrir que, contrariamente a las otras historias que se narran en la obra, en donde la música juega un papel muy importante, en la historia de las fotografías no hay música, solo escuchamos a veces la versión en armónica del Bolero de Ravel que Paco toca más para sí mismo que como parte de la historia. 
El segundo grupo de personajes importantes en la obra no tienen una identidad definida. Son hombres sin nombre ni apellido, porque representan a todas esas colectividades sin rostro que desaparecieron sacrificadas y de las cuales las historias oficiales y los medios en general poco han hecho por revivirlas. Sin embargo, dentro de la estructura dramática, conforman un coro eficiente que nos irá narrando y comentando cómo era el infierno para los que estuvieron allí. El despliegue de humor negro e ironía con el que el coro relata diferentes aspectos del exterminio es, sin duda, memorable también:

\section{Sueño de la Muerte}

Preso 4: Treinta y cinco maneras de morir en Mauthausen.

Preso 1: En esto entró una que parecía mujer, muy galana. Un ojo abierto y otro cerrado, vestida y desnuda de todos los colores; por un lado era moza y por el otro era vieja; unas veces venía despacio y otras deprisa; parecía que estaba lejos y estaba cerca, y cuando pensé que empezaba a entrar estaba ya a mi cabecera. ¿Quién eres?

Preso 3 (ataviado como la muerte, muy galana, con peluca, liguero y gorra de las SS): La Muerte.

Preso 1: ¿La Muerte? ¿Pues a qué vienes?

Preso 3: Por ti.

Preso 1: ¡Jesús mil veces! Según eso, me muero.

Preso 3: No te mueras. Vivo has de venir conmigo a hacer una visita a los difuntos, que pues han venido tantos muertos a los vivos, razón será que vaya un vivo a los muertos y que los muertos sean oídos. Venga, ven conmigo.

Preso 1: Pero yo no veo señas de la muerte por ninguna parte, porque a ella nos la pintan unos huesos descarnados con su guadaña.

Preso 3: Eso no es la muerte, sino los muertos o, mejor, lo que queda de los vivos. La muerte no la conocéis, y sois vosotros mismos vuestra muerte, tiene la cara de cada uno de vosotros y todos sois muertes de vosotros mismos; la calavera es el muerto y la cara es la muerte y lo que llamáis morir es acabar de morir y lo que llamáis vivir es morir viviendo. En este lugar hay tantas muertes como personas. ¿Qué miras?

Preso 1: Miro el Infierno, y me parece que lo he visto otras veces.

Preso 3: Este es el Infierno, en él vives y en él están las muchas muertes. Está la muerte de frío, la muerte de hambre, la muerte de miedo, la muerte de sed, la del palo, la del ahogado, la del ahorcado, la del electrocutado, degollado, desangrado, aplastado, gaseado, desmembrado, fusilado, despeñado... 
Preso 2: Asfixiado en el camión, quemado vivo, troceado a hachazos...

Preso 4: Despedazado por los perros, víctima de experimentos médicos...

Preso 2: Por inyección letal en el corazón, por enfermedad, a latigazos, por suicidio real o inducido...

Preso 4: ...tiro en la nuca, envenenado...

Preso 2: ...decapitado, extenuado, acuchillado, apedreado, estrangulado...

Preso 4: ...sepultado, pateado, trepanado y reventado, en total treinta y cinco.

Preso 1: ¿Nos dio Dios una vida sola y tantas muertes?; ¿de una manera se nace y de tantas se muere? Si yo vuelvo al mundo, procuraré empezar a vivir.

Preso 3: ¡Muertos, muertos, muertos! ¿Volver al mundo? De aquí sólo se sale convertido en humo y por la chimenea. (7-8)

Paul Ricken, el narrador alemán, es el encargado de relatar algunos de los sucesos que su cámara Leica plasmó para la posteridad. David Wingeate Pike nos dice que este personaje "never laid a hand on a prisoner, or if he did, prisoners noticed that he would do it only for effect ... Paul Ricken was that supreme rarity in Mauthausen or anywhere in die Totenkopfverbände: a man of common decency" (136). Asimismo, las investigaciones de Wingeate nos revelan que las cinco copias de muchos de los sucesos terribles que ocurrían en el campo y que iban a parar a manos de varios de los SS, quienes las solicitaban, eran totalmente ilegales aunque una práctica muy común en Mauthausen: "He was deep in graft ... in the context of the photolab [that] consisted of agreeing to there quest of SS personnel to develop and print their private photographs ... These photos included privately taken shots of camp atrocities, which was strictly forbidden, and SS men who were caught out could find themselves instants prisoners" (137). Wingeate, basándose en las entrevistas que pudo hacer a Antoni García, uno de los dos españoles que trabajaron en el laboratorio con Ricken, asegura que "he genuinely deplored the savagery, ... he was sickened at the sight of executions" (137). Esta imagen del fotógrafo Ricken como persona es la que los autores de El triángulo azul reproducen y quieren preservar para la memoria, en un intento por trascender las narrativas fácilmente maniqueas, y por darle a todos los participantes de estas historias su justa perspectiva, incluso corriendo el riesgo de generar incredulidad entre los lectores/espectadores. Vemos entonces que el Ricken de El triángulo se siente profundamente avergonzado de las actuaciones de ciertos altos mandos:

Ricken: Pocas veces he sentido más vergüenza. Aquel día el trabajo acabó mucho antes en la cantera. Como suboficial responsable del servicio de identificación fui el 
encargado de inmortalizar el acontecimiento. Con mi Leica retraté el carro, al reo, los músicos, los oficiales...

Brettemeier: Nadie puede escapar del campo. Esto es lo que les espera a todos los que lo intenten. De aquí sólo se sale convertido en humo y por la chimenea del crematorio.

El kapo pone la soga en el cuello del reo y aprieta el nudo. El reo susurra como en un trance.

Bonarewitz: Kamaraden! Soyez bons, aimez-vous les uns les autres!

De una patada, la banqueta que sujeta los pies del austriaco sale volando. Su cuerpo se agita, se retuerce y, por fin, se detiene. Un chorro de orina escurre por el pantalón del drillich y salpica a los espectadores de la primera fila.

Ricken: Ninguno de los supervivientes podremos olvidar aquella estúpida bufonada. (11)

Una de las fortalezas de los distintos filmes y trabajos documentales que se han producido a lo largo de los años sobre el tema del Holocausto es precisamente la imagen fotográfica, que habla más fuerte y con mayor eficacia que cualquier otro tipo de texto. ${ }^{13}$ El escenario, en este sentido, puede a veces representar una limitante en cuanto a sus posibilidades de recreación y de impacto, sobre todo en una obra que maneja de manera simultánea, y no en forma linear, varios espacios y tiempos. Sin embargo, en El triángulo azul no se deja nada a la imaginación y otro de los elementos dramáticos especialmente eficaces de esta obra es la inclusión de partes de documentales (reales) que fueron tomados durante y después de la guerra, que se proyectan en el escenario como parte de la escenografía. La combinación de actuación y apoyo visual es muy eficiente para despertar en los espectadores los sentimientos más intensos que casi de inmediato, garantizan la necesaria empatía. ${ }^{14}$ Además, como Susan Sontag sugiere, "la mayor vocación de la fotografía es explicar el hombre al hombre" (160).

Para finalizar, quiero retomar el tema de la música, porque le asigna a esta obra un carácter único y original. Como he dicho antes, la propuesta teatral de Ripoll y Llorente es un vodevil del horror, y no sería raro que la idea hubiese nacido del deseo de recuperar el vodevil que algunos entusiastas prisioneros españoles montaron en la Navidad de 1942, después de haber recibido la autorización para hacerlo:

Ricken: Aquellos españoles no paraban de tentar a la suerte. El colmo fue en la Navidad del 42.

Preso 1: Señoras y señores, meine damen und herren, madamemesiés, compatriotas, prisioneros, señores verdes, señores rojos, malvas, rosas, negros, amarillos ... 
señores de la autoridad competente ... la fabulosa compañía de revista "La Española" del Konzentrationslager Mauthausen (¡toma castaña!, para que luego digan que a los españoles se nos dan mal los idiomas) tiene el placer de presentarles la maravillosa revista musical titulada "El Rajá de Rajaloya”. ¡Música, maestro!

Música de pasodoble y grupo de presos que entra enseñando pierna y luciendo escote peludo.

Ricken: ¡Un espectáculo de variedades en medio de aquel horror! ¡Un espectáculo frívolo, repleto de hombres travestidos, chistes obscenos, bailes, pelucas y chisteras conseguidas sabe Dios cómo! Como tampoco sabremos nunca cómo se las ingeniaron para conseguir el permiso del Hauptsturmführer para hacer la representación, ni cómo hicieron para conseguir tela, madera y pintura para los decorados, ni tiempo para pintarlos y construirlos. El colmo del grotesco, el humor de Francisco de Goya hecho carne de escenario, aunque bien es verdad que poca. Los grabados de Goya en movimiento. Y, por encima de todo, aire fresco, diversión, moral para aquella tropa de hombres deshechos, diezmados, reventados, que sabían que la dignidad y la moral era lo único que les podía mantener con vida. Y es que en la Navidad de 1942 casi un setenta por ciento de los españoles que entraron en Mauthausen ya habían sido asesinados (17).

Creo que al igual que aquellos anónimos republicanos españoles, deseosos por hacer algo por sus compañeros en desgracia y ayudarlos a experimentar la esperanza aunque sin garantías, el teatro de Ripoll y Llorente busca el mismo tipo de objetivo, pero con garantías. El tema es atroz, rememorar (para quienes sí recuerdan) o enterarse de esas atrocidades no es entretenido ni divertido. Sin embargo, la música en este caso funciona como la spoon full of sugar, de Mary Poppins. El coro de prisioneros anónimos, acompañados por el grupo de músicos gitanos, dará buena cuenta en la Canción de la cantera de Wienergraben del exterminio por explotación, debido a las muchas horas de trabajos forzados, la poca comida y el poco descanso. También nos cantarán el Chotis del Crematorio, que una vez construido en Mauthausen, no dejó de funcionar hasta que los aliados estadounidenses liberaron el campo: "El crematorio, el crematorio, el crematorio / no da abasto con el gas, / y el que llega con los muertos / pa echarlos al crematorio / ya no puede, ya no puede ni pasar" (24). El estribillo de Canción de la supremacía aria nos recuerda las narrativas imperialistas nazis, sobre las que fundamentaron el exterminio:

Aria soy como Parsifal, / aria soy como Loengrin, Sigfrido, / Thor y Wotán. / Sólo así podré yo lograr / una Europa más aria y total. / Sólo así podré exterminar / a 
judíos, gitanos, / maricas, rojos y demás. / Aria soy como Parsifal, / soy lo más, / viva yo, / viva el gas. (29)

Por su parte, la Canción del Revier y el banderillero nos narra la terrible suerte de muchos de los prisioneros víctimas de experimentos pseudocientíficos:

Porque es que allí sus doctores / a ti te destriparán, / te abrirán como a un conejo / y así experimentarán. / Y es que por cualquier cosita / te ponen una inyección / de Cloruro de magnesio / en todito el corazón. (31)

O la Canción de la alambrada electrificada, que nos relata cómo algunos ya sin esperanza terminaron sus días allí:

Cuando estés desesperado, / si del horror te has cansado, / ven, que tengo un cablecito / que te va a dejar fritito / y todo se habrá acabado. / Mis besos te abrasarán, / mi abrazo te quemará, / ven, que tengo un cablecito / que te deja pajarito / y el sufrir terminará. (41)

Las letras de todas estas canciones rezuman el sello dramático de Ripoll: ironía, sarcasmo, humor negro, construcción de escenas grotescas cuya efectividad es incuestionable. Es interesante notar que, salvo por el tipo de música, podría tratarse de corridos e incluso, si queremos ir un poco más lejos en el pasado, de romances como los que cantaban los juglares para contar las desgracias o las hazañas. ${ }^{15}$ Esta combinación de relato y música resulta muy interesante, porque de muchas maneras la obra nos invita a burlarnos de la barbarie y de los totalitarismos, a ridiculizarlos, para combatirlos poco a poco. La ironía es el eje discursivo de la historia y, como apunta Linda Hutcheon, transmite actitudes y sentimientos, pero también, al establecer una relación especial entre lo que se dice y lo que no, nos confronta como lectores/espectadores a la inferencia no sólo de significados, sino también de actitudes y de concepciones (37). No olvidemos que El triángulo azul es una obra que enfrenta el olvido intencional; en este contexto, la ironía se convierte en un acto de habla perlocucionario, ya que produce "certain effects upon the feelings, thoughts, oractions of the audience, or of the speaker, or of other persons" (Austin 101) y los efectos en el espectador no se hacen esperar: la posibilidad de interpretar las ironías y de experimentar indignación, asombro, tristeza, compasión, pero también el deseo por conocer más y actuar. ${ }^{16}$ Asimismo, la ironía es una manera de ocultar la hostilidad y crear la imagen de distanciamiento, por lo que no es coincidencia que, en la obra 
que nos concierne, Paco sea el portavoz principal de la ironía y el sarcasmo, como una especie de máscara para poder resistir el horror y actuar.

Pero una de las funciones más populares de la ironía es la lúdica, que nos lleva al dominio del humor, del ingenio y la jocosidad (Hutcheon 46). El sarcasmo y el humor negro sirven de contrapeso al vacío de sentido que definió los campos de exterminio. Si el valor de la vida humana ha sido cuestionado en estos campos, por qué no polemizar dramáticamente sobre el valor de la muerte, burlarse y reírse un poco de ella y, a la vez, debatir con quienes estuvieron y están interesados en olvidar, en pactar para el futuro. Me parece que esa ha sido la función del coro en las distintas canciones de la obra. ${ }^{17}$ Pero la obra también nos lleva a objetar nuestro rol como lectores/espectadores y, de cierta manera, movernos a actuar para dejar de ser cómplices del olvido. La representación dramática de esta postmemoria supone sin duda el rechazo a la política silenciadora del franquismo que siguió funcionando después de la muerte del dictador. No hay duda de que Ripoll y Llorente han querido restituir a las víctimas españolas del Holocausto el espacio de memoria que les corresponde por derecho y, en este sentido, lo que nos han ofrecido es una celebración.

University of South Carolina

NOTAS

1 Hasta el momento de estar escribiendo el artículo la obra no había sido publicada, por lo que Laila Ripoll me hizo llegar muy generosamente el manuscrito original electrónico (en Word). Quiero agradecerle a la dramaturga su interés por apoyarme en este trabajo.

2 Entendemos por memoria histórica todo aquel "conjunto de hechos reprimidos que están en la memoria de la gente pero no forman parte de la historia" (Parodi 15). En este sentido, la recuperación de la memoria histórica presupone no solo recuperar el recuerdo que por alguna razón fue olvidado, sino además recuperar lo que a esos colectivos olvidados les pertenece. El movimiento en España que ha presionado para que se reabran las fosas comunes es un buen ejemplo de esto último.

3 No olvidemos que en 1977 se acuerda una Ley de Amnistía que pretende liberar de toda culpa a los responsables de los crímenes durante la Guerra Civil y la posguerra.

4 En el campo de la narrativa en prosa hay sin duda títulos muy importantes, como Soldados de Salamina (2001) de Javier Cercas, Si te dicen que caí (1973) de 
Juan Marsé, Los Santos Inocentes (1981) de Miguel Delibes (así como el film sobre la novela) y Luna de lobos (1985) de Julio Llamazares. Asimismo Nada (1943) de Carmen Laforet que, aunque fue escrita durante el franquismo, es un buen ejemplo de reconstrucción literaria de la memoria. En el ámbito teatral hay también obras significativas, como Hoy es fiesta (1956) y El tragaluz (1967) de Antonio Buero Vallejo, Guernica (1969) de Jerónimo López Mozo, o La muerte de García Lorca (1969) de José Antonio Rial, solo por mencionar algunas.

5 Aparentemente, vivimos en una cultura de la memoria trasnacional, cuyas formas espectaculares en la esfera pública, vigentes en las prácticas de la retórica memorialista, importan tropos empleados en las narrativas del Holocausto para la construcción de capital político a partir de la victimización judía.

6 De acuerdo con el periodista Carlos Hernández de Miguel - autor de Los últimos españoles de Mauthausen, así como de un sitio web muy completo sobre este tema (deportados.es) y de una cuenta en Twitter (@deportado4443), en donde tiene muchos seguidores -: “9.328 españoles pasaron por los campos de concentración nazis, entre ellos 300 mujeres. Cerca de 5.500 sólo pudieron escapar convertidos en humo y cenizas, a través de la chimenea del crematorio" (Pato). Asimismo, el periodista revela que el destino de los republicanos españoles en Francia lo decidió el gobierno del General Franco, no Hitler: "Hitler jamás habría enviado a esos 9.30o españoles a los campos de concentración sin el consentimiento de Franco. Los españoles, tras ser capturados por los nazis durante la invasión de Francia, son enviados junto a soldados británicos y franceses a campos de prisioneros de guerra. En estos campos se respetaba la Convención de Ginebra. Todo cambió con esa visita de Serrano Suñer a Berlín en septiembre de 1940. Tras reunirse con Hitler, Himmler y con toda la cúpula del III Reich, Alemania emitió una orden a la Gestapo para que sus agentes sacaran a los españoles, y solo a los españoles, de esos campos de prisioneros de guerra para enviarlos a campos de concentración ... Esa orden se emitió el 20 de septiembre de 1940, mientras Serrano Suñer abandonaba Berlín" (Pato).

7 Cabe precisar que la primera obra que se publica sobre el tema de los españoles víctimas de los campos de concentración nazi es Los catalanes en los campos nazis, de Monserrat Roig, publicado en catalán primero en 1977 y un año después, en español. Roig consiguió reunir un buen número de testimonios de personas que sufrieron la experiencia en algunos de los campos de concentración nazis, para dar voz a aquellos que habían luchado contra el fascismo en Europa, y también a aquellos que murieron. La inspiración de Roig sobre este tema viene principalmente de su lectura de la obra de Pere Vives, Cartes des dels camps de concentració de 1972, así como de 
su contacto con la asociación legalizada en 1978 "Amical de Mauthausen y otros campos y de todas las víctimas del nazismo de España”, según la investigación de Pepa Novell (135).

La obra se estrenó el ํㅜ de mayo de 2014 en el Teatro Valle-Inclán de Madrid; la dirección estuvo a cargo de Laila Ripoll, la escenografía la creó Martín Burgos y la iluminación Luis Perdiguero. En el reparto: Manuel Agredano, Elisabet Altube, Marcos León, Mariano Llorente, Paco Obregón, José Luis Patiño y Jorge Varandela. La producción estuvo a cargo del grupo Micomicón y el Centro Dramático Nacional. La obra ganó dos premios Max en 2015: uno por la mejor autoría teatral y otro por la mejor escenografía.

9 En 2003 aparece el estudio de David Wingeate Pike intitulado Spaniards in the Holocaust: Mauthausen, Horror on the Danube. Me parece que una buena parte de la personalidad dramática del narrador en la obra se inspiró en este trabajo.

1o El triángulo azul es un montaje respaldado por una rigurosa documentación, fundamentalmente por los estudios de Benito Bermejo, Montserrat Roig y David Wingeate Pike, así como los testimonios de los supervivientes, como Constante, Razola, Gaitero, Laffite, Juan Deportado o De Diego, según el reporte de Verónica Viñas.

11 La clara oposición narrativa entre la música clásica y la música popular que podemos observar en la obra nos lleva a percibir un juego irónico entre lo que algunos consideran la "alta cultura", es decir, los productos culturales que han sido reconocidos por la cultura hegemónica como prestigiosos y la "baja cultura”, o la cultura de las masas populares, de menor prestigio. En el contexto de la fábula, la "alta cultura" es la que representa a los poderosos, al imperio, y se opone a la que introduce y habla de los dominados, los que están en una posición claramente inferior.

12 Este es uno de los temas más complicados y menos tratados sobre el Holocausto. De hecho, no será hasta el año 2010 cuando se publique el primer libro que se centra sobre este tema: La violencia sexual contra las mujeres judías durante el Holocausto. Asimismo, parece ser que se trata de un tema muy incómodo entre muchos estudiosos del Holocausto, al punto de incluso negar su posibilidad (Ravitz). Aparentemente, la voz de las sobrevivientes judías violadas durante su estadía en los campos de exterminio es mejor que no se escuche, "por el bien común", según el artículo de Ravitz.

13 Según Alvin Kernan, las imágenes visuales no comunican lo mismo que las palabras; lo que dicen no es necesariamente inferior, pero sí diferente. El sentido en las imágenes reside en la superficie y se experimenta de inmediato en lugar de requerir de un extenso análisis, como suele suceder con los textos tradicionales. El sentido de la imagen visual es, además, mucho menos complejo porque no presupone la multiplicidad semiótica de la palabra ni la ambivalencia irónica que se establece entre las palabras (Kernan 148). Según 
Susan Sontag, por su parte, la fuerza de la fotografía "preserva abiertos al escrutinio instantes que el flujo normal del tiempo reemplaza inmediatamente" (16o); es por ello que la fotografía nos permite reconocer, no comprender.

14 Los comentarios de la crítica han sido muy positivos con la obra de Ripoll y Llorente; la escenografía, que incluye la proyección de partes de documentales reales, ha resultado uno de los aspectos que más elogios ha conseguido, junto con la actuación y con el texto teatral.

15 El corrido es un género musical mexicano que se desarrolla en el siglo XVIII; se trata de una narrativa popular en forma de balada que trata de temas políticos, eventos históricos y/o de amoríos. Su papel de fuente de información sobre los movimientos, las victorias y las pérdidas en la revolución lo acerca, desde mi análisis, a los romances de los juglares, muchos de los cuales tenían la misma función. En la obra, las diversas canciones "nos informan" de los distintos tipos de horrores que se vivieron en Mauthausen.

16 Para Hutcheon, "the final responsibility for deciding whether irony actually happens in an utterance or not (and what the ironic meaning is) rests, in the end, solely with the interpreter" (42).

17 Es cierto que, al introducir humor y sarcasmo como elementos primordiales, Ripoll y Llorente se arriesgaban a que su obra trivializase la historia. Lejos de ello, en las diferentes críticas que pueden encontrarse en línea sobre la respuesta que la obra ha tenido, lo que encontramos son públicos emocionados y conmovidos, que han aplaudido a los actores por varios minutos.

OBRAS CITADAS

AGENCIA ESTATAL. "Ley 52/2007, de 26 de diciembre, por la que se reconocen y amplían derechos y se establecen medidas en favor de quienes padecieron persecución o violencia durante la guerra civil y la dictadura". Boletín Oficial del Estado 310 (27 diciembre 2007): 53410-53416. Web

Els nens perduts del franquisme. Dir. Armengou, Montse y Ricard Belis. Televisiò de Catalunya, Barcelona, 20 de enero de 2002. Televisión.

ASSMANN, ALEIDA. "Re-framing Memory: Between Individual and Collective Forms of Constructing the Past". Performing the Past: Memory, History, and Identity in Modern Europe. Eds. Karin Tilmans, Frank van Vree, y Jay Winter. Amsterdam: Amsterdam UP, 2010. 35-50.

AUSTIN, JOH n. How to Do Things with Words. Oxford: Oxford UP, 1975.

B E N E T T, J IL L. Emphatic Vision. Affect, Trauma and Contemporary Art. Standford:

Standford UP, 2005. 
Bermejo, Benit o. Francisco Boix, el fotógrafo de Mauthausen. Fotografías de

Francisco Boix y de los archivos capturados a los SS de Mauthausen. Barcelona: RBA, 2002.

DE LGAD o, MARÍA M. "Memory, Silence, and Democracy in Spain: Federico García

Lorca, the Spanish Civil War, and the Law of Historical Memory". Theatre

Journal 67.2 (2015): 177-196.

ENG ELKING, BARBARA. Holocaust and Memory. London: Liecester UP, 2001.

GALIN D 0, CAR Los. "Estreno absoluto de Atra Bilis de Laila Ripoll, y otros dramas".

$A B C$.es 23 febrero 2001. S.pag. Web.

HERNÁNDEZ, CARLOS. "Los deportados españoles en Mauthausen y los datos que

deberían estar en los libros de historia". Eldiario.es 26 enero 2015. S.pag. Web.

HIRSCH, MARIANNE. The Generation of Postmemory: Writing and Visual Culture

After the Holocaust. New York: Columbia UP, 2012.

"Holocaust". Encyclopædia Britannica Online. 2015. S.pag. Web.

но ғ ғ м An, Eva. After Such Knowledge: Memory, History, and the Legacy of the

Holocaust. New York: Public Affairs, 2004.

Hu T C E ON, LIN DA. Irony's Edge: The Theory and Politics of Irony. New York: Taylor

\& Francis e-Library, 2005.

Juicio a los principales criminales de guerra alemanes. 28 enero 1946. S. pag. Web.

KA Ku T A I, м IC ні ко. "Milan Kundera: A Man who Cannot Forget". The New York

Times 18 January 1982. S. pag. Web.

KERNAN, ALVIn. La muerte de la literatura. Caracas: Monte Ávila, 1996.

NOVELL, PEPA. "El recuerdo del Holocausto y 'el caso Marco': deber de memoria,

abusopreventivo o memoria para el triunfo". Letras Peninsulares 22.2 (2010):

129-153.

PARO D I MUÑ OZ, MAN UEL. Perspectivización de la memoria histórica en la narrativa

españolaactual. Berlín: Tranvía-Verlag Walter Frey, 2013.

PASCUA L, I TZí AR. “Abrir los ojos” Introducción. Los niños perdidos. Por Laila Ripoll. 3-5. Web.

PAT 0, I G NACio. "Hitler siguió órdenes de Franco para exterminar a 9.328

españoles". Playground Noticias. 2 junio 2015. S. pag. Web.

PREST ON, PAUL. The Spanish Holocaust: Inquisition and Extermination in Twentieth-

Century Spain. New York-London: N.W. Norton \& Company, 2012.

RAVITZ, JESSICA. "Las historias no contadas sobre violencia sexual durante el

Holocausto". CNN México 2 julio 2011. S. pag. Web.

RECK, IS A B E LLE. "El teatro grotesco de Laila Ripoll, autora". Revista Signa 21 (2012): $55-84$.

RIPOLL, LAILA Y MARIANO LLORENTE. El triángulo azul. S.f. Manuscrito.

Francisco Boix, un fotógrafo en el infierno. Dir. Lorenzo Soler. Canal +, 2000.

son TAG, susan. Sobre la fotografía. México: Alfaguara, 2006. 
VIÑAS, VERóniCA. "El vodevil de Mauthausen". Diario de León.es 20 enero 2015. S. pag. Web. 